\title{
A DIFFÚZIÓS HIDROGÉNTARTALOM HEGESZTETT KÖTÉSEKRE GYAKOROLT HATÁSA
}

\author{
Kovács Judit \\ PhD hallgató, Miskolci Egyetem, Anyagszerkezettani és Anyagtechnológiai Intézet \\ 3515 Miskolc, Miskolc-Egyetemváros, e-mail: metkjudit@uni-miskolc.hu \\ Ahmad Yasser Dakhel \\ PhD hallgató, Miskolci Egyetem, Anyagszerkezettani és Anyagtechnológiai Intézet \\ 3515 Miskolc, Miskolc-Egyetemváros, e-mail: yaser.dakhel@gmail.com

\section{Lukács János} \\ egyetemi tanár, Miskolci Egyetem, Anyagszerkezettani és Anyagtechnológiai Intézet \\ 3515 Miskolc, Miskolc-Egyetemváros, e-mail: janos.lukacs@uni-miskolc.hu
}

\begin{abstract}
Absztrakt
A hidrogén okozta repedés, illetve a hidegrepedés egy gyakran elöforduló károsodási mechanizmus, ami a fémek és az ötvözetek többségére hatással van. A hidegrepedést számos külsö és belsö paraméter befolyásolja, igy a repedéskialakuláshoz hozzájáruló tényezők meghatározása gyakran nehézségbe ütközik. Jelen áttekintö cikkben, hazai és nemzetközi szakirodalmi források alapján, a hidrogén elöfordulását, oldhatóságát, diffúzióját és mennyiségi maghatározásának a lehetöségeit vizsgáljuk, valamint a hidegrepedés mechanizmusát és kialakulásának lehetséges megakadályozási módjait foglaljuk össze.
\end{abstract}

Kulcsszavak: diffúzióképes hidrogéntartalom, hidrogén okozta repedés, hidegrepedés, hegesztés, acélok

\begin{abstract}
Hydrogen assisted cracking, or cold cracking is a common failure mechanism that affects most metals and alloys. Cold cracking is affected by several external and internal parameters, so determining the factors that contribute to crack formation is often difficult. This review examines the solubility, diffusion, and measurement of hydrogen based on domestic and international literature and summarizes the mechanism of cold cracking and the possibilities to prevent it.
\end{abstract}

Keywords: diffusible hydrogen content, hydrogen assisted cracking, cold cracking, welding, steels

\section{Bevezetés}

A hidrogén és a fémek között fellépő kölcsönhatás, mind tudományos mind ipari szempontból, fokozott figyelmet kapott az elmúlt évtizedekben. Ez a figyelem az egy-egy szükebb területre (például hegesztés vagy csővezetékes termékszállítás) való fókuszálás mellett kiterjed, illetve elvezet a szerkezetintegritás [1,2] világába, lényegesen összetettebb megközelítést megcélozva.

A hidrogén fémekre gyakorolt káros hatása hidrogén okozta ridegedésként (hydrogen embrittlement) vagy hidegrepedésként (cold cracking) ismert. Erről a jelenségről már 1875-ben beszámolt W. H. Johnson, a következőt írva: „Ez a mindenki számára nyilvánvaló változás különösen csökkenti a vas keménységét és szilárdságát és még figyelemre méltóbb, hogy a változás nem állandó, csak átme- 
neti jellegü, mert idővel a fém visszanyeri eredeti szívósságát és szilárdságát”. Az 1920-as évektől a hidrogén káros hatásai felkeltették a kohászok, a vegyészek és a fizikusok érdeklődését. A hidrogén okozta ridegedés mechanizmusára Zapffe és Sims alkotta az első látványos modellt, 1941-ben. Feltételezték, hogy a hidrogén összegyülik az anyagok mikroüregeiben és egyéb anyagfolytonossági hiányainak a környezetében, ahol nagy nyomás alakul ki. Feltételezésüket nem támasztották alá fémfizikai megfigyelések, de az alapgondolatot több későbbi elmélet is felhasználta. A hidrogén hegeszthetőségre gyakorolt hatásának első vizsgálatait az 1940-es években, az Egyesült Államokban végezték, Rollason ötvözött acélokon, Flanigan pedig lágyacélokon végzett vizsgálatokat. Az 1970-es években összegezték a hidrogén okozta ridegedés elméletét és leírására különböző modelleket készítettek.

A hidrogénnel kapcsolatos vizsgálatok napjainkig folyamatosak voltak és még mindig vannak megválaszolatlan kérdések és fejlesztési lehetőségek, különösen az anyagok szüntelen fejlesztésének köszönhetően. Annak ellenére, hogy a nagyszilárdságú acélokat jól hegeszthetőnek tekintik, a hegesztéssel kapcsolatos követelmények a szilárdság növekedésével egyre szigorúbbak. Különösen a 960 MPa folyáshatár feletti (jellemzően bénites, martenzites szövetszerkezü) acélok esetén jelent problémát a hidrogén okozta elridegedés. Ezekben az acélokban a diffúzióképes hidrogéntartalom, a feszültség és a repedésre hajlamos szövetszerkezet kombinációjának köszönhetően, a hegesztést követöen a hőhatásövezetben és a varratban egyaránt előfordulhat hidegrepedés [3-7].

\section{A hidrogéntartalom forrása}

A hidrogén abszorpciója az acélokban bekövetkezhet az acélgyártás vagy a későbbi üzemelés során is, például különböző hőkezelő eljárások vagy hegesztés esetén. Ez meghatározott terhelési körülmények között mechanikai tulajdonságromlást, hidegrepedést okozhat. Általában a hidrogén gáz formában, vagy a hidrogén tartalmú folyékony fázisok elektrokémiai redukciója útján jut a fémekbe. Ez a folyamat sok különböző paraméter függvénye. Az első esetben ezek főként környezeti tényezők, mint például az alkalmazott nyomás, a gáz tisztasága és a hőmérséklet. A második esetben a domináns tényezők az elektrolit-fém határfelület potenciája, az alkalmazott áramsürüség, az elektrolit összetétele és az oldat $\mathrm{pH}-\mathrm{ja}[3,8]$.

A hegesztés közben a hidrogén abszorpciója a gáznemủ molekuláris hidrogén disszociációjával történik az ívoszlopban. A hidrogén forrása hegesztéskor a légkör, a hegesztési hely környezetében megjelenő víz, amelynek eredete a lecsapódó pára, a csapadék, a bevonat vagy a fedőpor nedvességtartalma, illetve a védőgáz, valamint az alapanyag vagy a hozaganyag felületén található rozsda és más szennyeződés, szerves anyag (festék, zsír, olaj). Korábbi kutatások kimutatták, hogy a hegesztési paraméterek befolyásolhatják a varratok diffúzióképes hidrogéntartalmát. Az eredmények azt mutatták, hogy a megnövekedett áramátadó távolság (az áramátadó és a munkadarab közötti távolság) csökkenti a hidrogéntartalmat. A megnövekedett áramátadó távolsággal megnő a huzal szabad hossza és az idő, így a hidrogén el tud távozni a hozaganyagból, még mielőtt elérné az ívet. Ezenkívül, a hegesztési feszültség (ívhossz) is hatással van a hidrogéntartalomra. A megnövekedett feszültség nagyobb ívhosszat eredményez, így több hidrogén tud disszociálni, viszont állandó áramátadó távolság esetén a szabad huzalhossz csökken, ami magasabb hidrogén koncentrációhoz vezet a varratban. Továbbá, a nagyobb huzalelötolási sebesség megnöveli a hozaganyag mennyiségét, ami szintén megnövekedett hidrogéntartalmat eredményez [9-12]. 


\section{A hidrogén oldhatósága}

A hidrogén acélban való oldhatósága függ a hőmérséklettől, a nyomástól és a kristályszerkezettől. A hidrogén oldhatóságának változása az acél különböző fázisaiban a hőmérséklet és a nyomás függvényében az 1. ábrán látható. Az ábrán jól látszik, hogy a hőmérséklet növekedésével a hidrogén oldhatósága ugrásszerủen növekszik, amikor a ferrit ausztenitté alakul; illetve az oldhatóság ugrásszerüen csökken, amikor az ausztenit delta-feritté alakul. A folyékony fázis elérésekor az oldhatóság hirtelen és erőteljesen megnő. A folyékony vasban a hidrogén oldhatósága $1600^{\circ} \mathrm{C}$-on 1 bar nyomáson 34 tömeg ppm-re tehető. Amikor a folyékony fémet gyorsan, nem egyensúlyi körülmények között szobahőmérsékletre hütik, az acélban visszamaradt hidrogén mennyisége jóval meghaladhatja az oldhatósági határértéket, mivel a hidrogén oldhatósága az acélban szobahőmérsékleten meglehetősen alacsony. A hidrogén oldhatósága a martenzitben 0,4 tömeg ppm, ami alacsonyabb, mint az auszteniben, de magasabb, mint a ferritben $\left(3 \cdot 10^{-4}\right.$ tömeg ppm) [13].

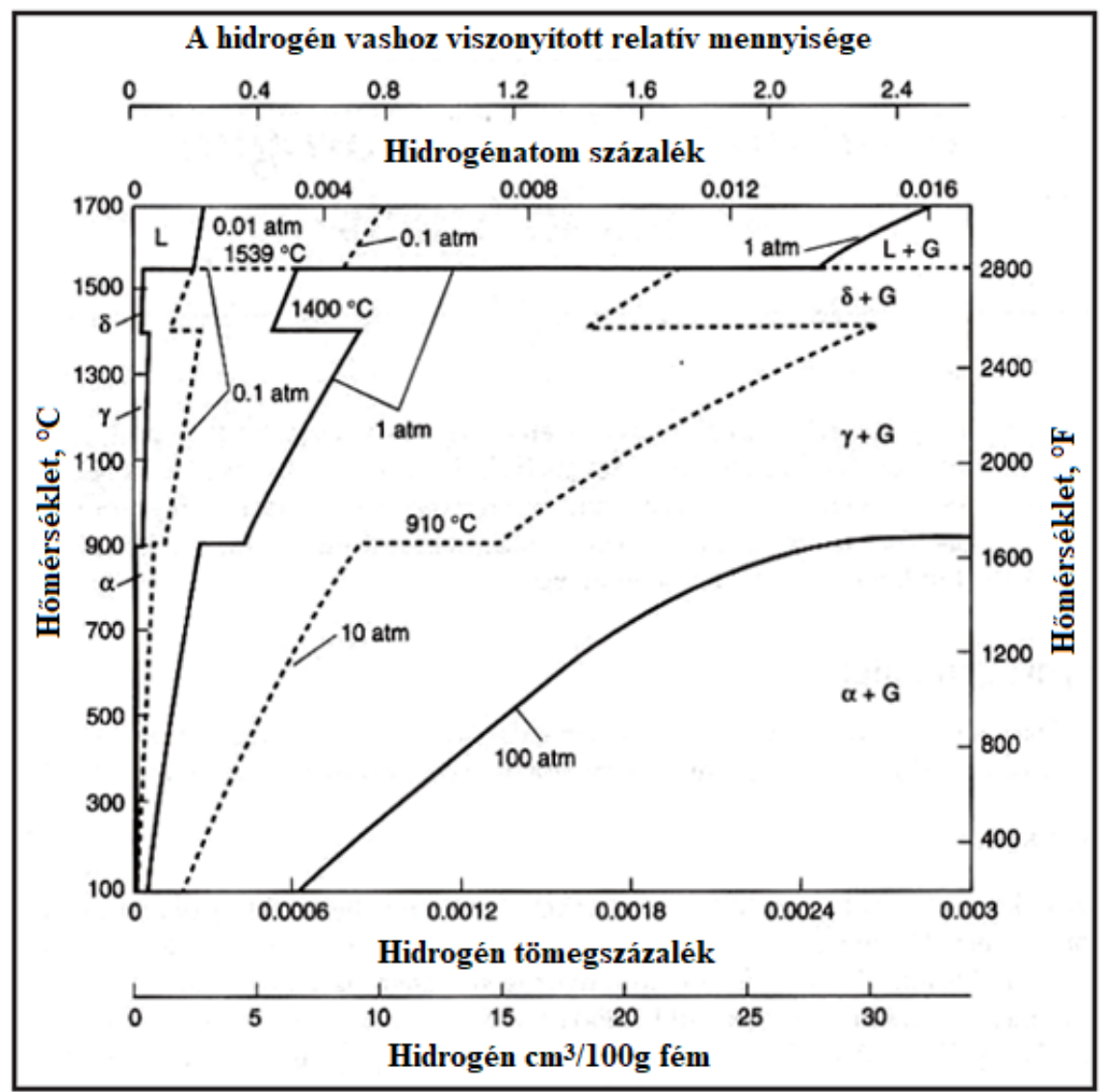

1. ábra. A hidrogén oldhatósága az acélban a hőmérséklet és a nyomás függvényében [13]

\section{A hidrogén diffúziója a hegesztett kötésben}

A hidrogén okozta ridegedés kezdeti folyamata a hidrogén anyagon keresztüli diffúziójához kapcsolódik. A hidrogén behatolása akkor kezdődik, amikor atomi hidrogén van a fém felületén, ezért hidrogén 
diffundálhat a fémbe. Nagy mennyiségủ hidrogén atom rekombinálódhat a fém belsejében $\mathrm{H}_{2}$-t képezve, amely nagy nyomás hatására gázbuborék formájában maradhat a fém belsejében. A repedések keletkezése és terjedése is a hidrogéntartalom ezen pontján történik. Ezért fontos felmérni, hogy a hidrogén diffúziója eltérő módon megy-e végbe a különböző szövetszerkezetekben, mint például az alapfémben és a varratban [14].

Az adszorpció és a disszociáció után a hidrogén abszorpcióval oldódik fel a légkörböl, a következőképpen [15]:

$$
\mathrm{H}_{2} \text { (gáz) }=2 \mathrm{H}(\text { oldott }) \text {; }
$$

a koncentrációja pedig a Sieverts törvény alapján írható le [15]:

$$
\mathrm{c}_{\mathrm{H}}=\mathrm{K}_{\mathrm{s}} \cdot\left(\mathrm{p}_{\mathrm{H} 2}\right)^{1 / 2} \text {, }
$$

ahol $\mathrm{c}_{\mathrm{H}}\left[\mathrm{mol} / \mathrm{cm}^{3}\right]$ az oldott $\mathrm{H}$ atomok koncentrációja, $\mathrm{K}_{\mathrm{S}}$ a Sieverts állandó, és $\mathrm{p}_{\mathrm{H} 2}$ [bar] a hidrogén nyomása a környezetben.

A hidrogén abszorpcióját nem csak a gáznemü hidrogén, hanem gyakran elektrolitok is okozhatják (például az acélok korróziója esetén). A vas savas környezetben történő korróziója során a Volmerreakció [15]:

$$
\mathrm{Fe}+2 \mathrm{H}^{+}=\mathrm{Fe}^{2+}+2 \mathrm{H}_{\mathrm{ad}}
$$

az adszorbeált $\mathrm{H}$ rekombinációja (Tafel reakció) [15]:

és a $\mathrm{H}_{\mathrm{ad}}$ adszorpció [15]:

$$
2 \mathrm{H}_{\mathrm{ad}}=\mathrm{H}_{2}(\text { gáz) }
$$

$$
\mathrm{H}_{\mathrm{ad}}=\mathrm{H}(\text { oldott })
$$

játszódik le. Ezeknek a reakcióknak a kölcsönhatása létrehozza az $a_{H}$ hidrogénaktivitást a fém felületén, amelyet erősen befolyásolnak az elektrolitban lévő inhibitorok és promóterek, valamint az ötvöző elemek és a szennyeződések jelenléte a fém felületén. A hidrogénaktivitást a $c_{H}$ hidrogénkoncentráció határozza meg, ami a $\mathrm{H}_{2} \mathrm{c}_{\mathrm{H}}{ }^{0}$ hidrogénkoncentrációhoz kapcsolódik $\mathrm{T}=0{ }^{\circ} \mathrm{C}$ hőmérsékleten és 1 bar nyomáson [15]:

$$
a_{H}=\frac{c_{H}}{c_{H}^{\circ}}=\left(\frac{p_{H_{z}}}{p_{H_{n}}^{\circ}}\right)^{1 / 2} .
$$

Ha az anódos oldódási reakció (3a) fokozódik (például kén jelenlétében) és/vagy a rekombinációs reakció (3b) késik (például arzenát miatt), akkor az acél felületén nagyon magas hidrogén aktivitás léphet fel, ami a hidrogén nagy mennyiségü abszorpcióját eredményezi [15].

\section{Hidegrepedés a hegesztett kötésekben}

A hidrogén okozta hidegrepedés az egyik leggyakoribb hiba főként nagyszilárdságú acélok varratainál, mert a hidrogén kívülről történő felvétele gyakorlatilag elkerülhetetlen. Késleltetett repedési karakterisztikája miatt, mivel $200{ }^{\circ} \mathrm{C}$ alatti hőmérsékleten a varratban, hőhatásövezetben vagy az alapanyagban is megjelenhetnek repedések, akár a hegesztés után több nappal is, komoly veszélyt jelent a szerkezeti biztonságra. A hegesztés következtében fellépő hidegrepedést általában a hegesztett kötésben három együttesen fellépő tényező okozza: a kemény szövetszerkezet (mint például a bénit vagy martenzit), a diffúzióképes hidrogén jelenléte és a magas (maradó) feszültségállapot (2. ábra). A hegesztett 
kötés kialakítása közben, különösképpen, ha nagyszilárdságú acélról van szó, az előbb említett három tényező az idő változásával összetett módon változik és egymást is befolyásolja [6, 11, 16-18].

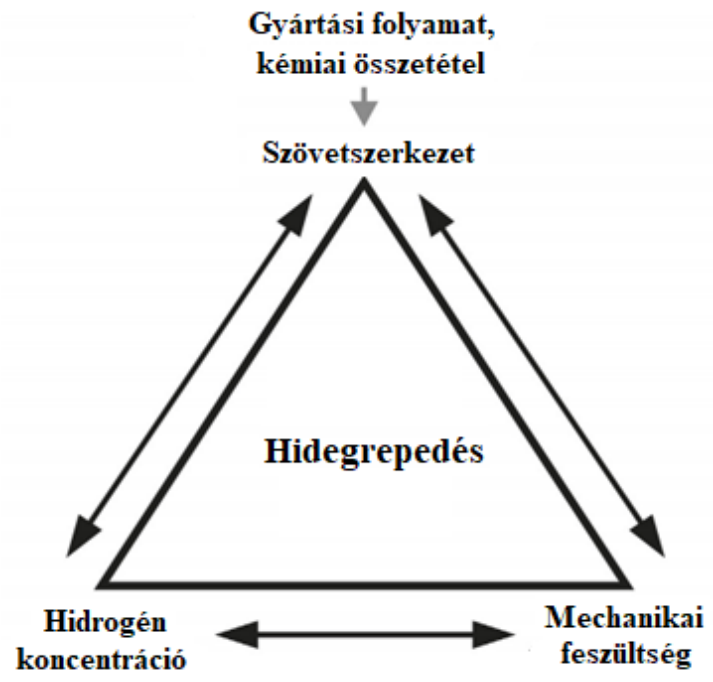

2. ábra. A hegesztés következtében fellépő hidegrepedést okozó három tényező [6]

Mivel a hidrogén okozta repedés jelenlétét, a 3. ábrán látható tényezők mellett, számos egyéb tényező is befolyásolja (mint például a terhelés módja és nagysága, a hidrogén anyagba jutásának módja, a próbadarab mérete, egyéb szövetszerkezeti tényezők), a hagyományos hidegrepedési vizsgálatok (tesztek) végeredményei nagy szórást mutatnak [19].

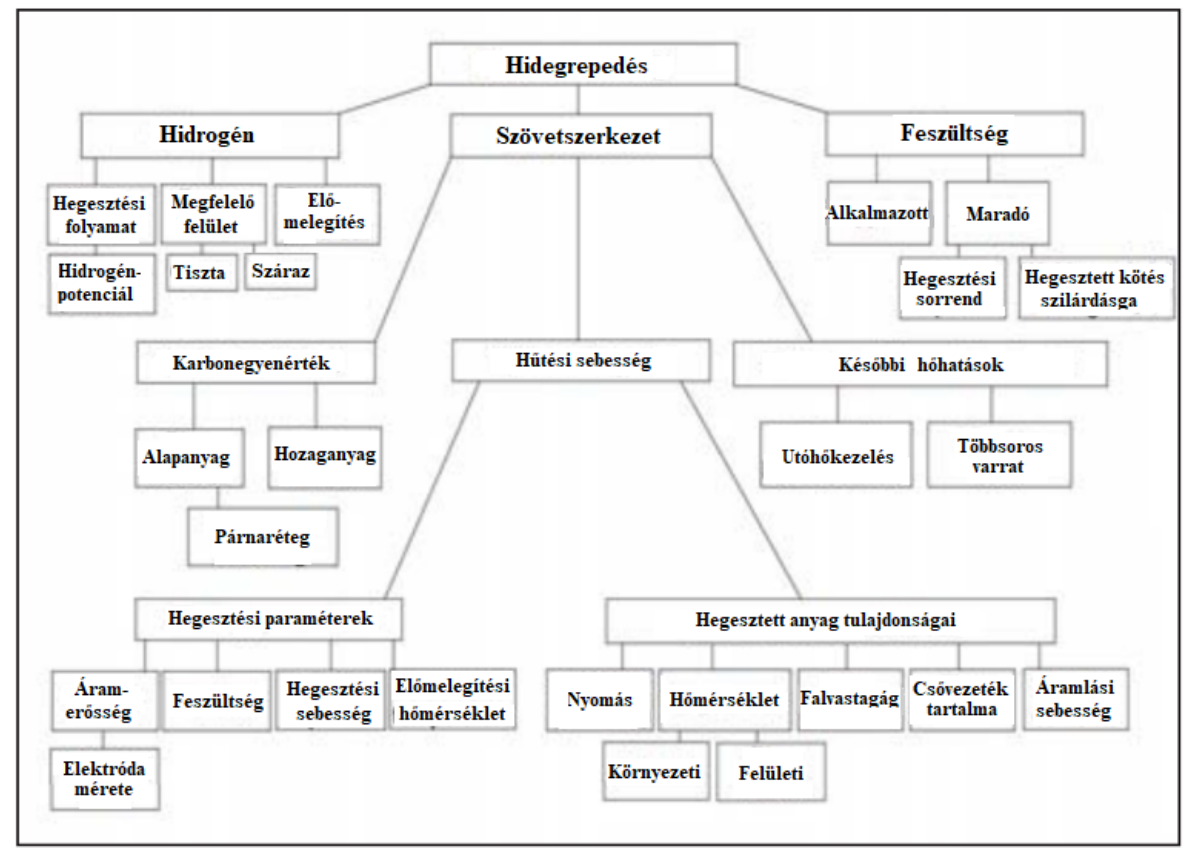

3. ábra. A hidegrepedést befolyásoló tényezők [13] 
A folyáshatár növelésével a mechanikai tulajdonságok jelentős romlása figyelhető meg diffúzióképes hidrogén jelenlétében. Ez csökkenő alakíthatósághoz és rosszabb alakváltozási képességhez vezet, amelynek következtében a mechanikai terhelések hatására hidegrepedés következhet be. A hidrogén okozta hidegrepedés kialakulásának esélye a húzófeszültség növelésével is növekszik, ezért a legfőbb megoldás a hidegrepedés jelenségének kiküszöbölésére a hidrogénszint csökkentése és az előmelegítés $[11,16,19]$.

Tekintettel arra, hogy a nagyszilárdságú acélok bénites és martenzites szövetszerkezetüek, a hegesztés során törekedni kell a minél kisebb hőbevitelre (kis t8/5-ös hülési időre), hogy a hegesztett kötés mechanikai tulajdonságai megfelelőek legyenek. A régebbi fejlesztésü, alacsonyabb szilárdságú acélok esetén a hidegrepedés jellemzően a hőhatásövezetben következett be, mivel hegesztés közben gyors hülés volt tapasztalható, így durvaszemcsés, nagy keménységủ zóna alakult ki. A 690 MPa vagy annál nagyobb folyáshatárú, nagyszilárdságú acélokban a repedésképződés előfordulhat a varratban is. Ötvözött acélok esetén az alapfém és a hozaganyag összetétele közel azonos, ennek megfelelően a varratban és a hőhatásövezetben ugyanaz az átalakulási folyamat játszódik le. Ilyenkor a diffúzióképes hidrogéntartalom nem tér el a hőhatásövezetben és a varratban, így hidegrepedésre egyformán hajlamosak lesznek. Nagy szilárdságú, alacsony ötvözésủ acélok esetén, ahol csökkentett a karbontartalom, az acél szilárdságát mikroötvözéssel és különböző termomechanikus módszerek alkalmazásával érik el, ezért a höhatásövezet és a varrat is ferrites marad, de a varrat hajlamosabb lesz hidegrepedésre, mint a höhatásövezet. Matsuda és kollégái tanulmányozták a hőhatásövezet elhelyezkedését a hegesztett kötésen belül. Tanulmányukban a hidrogénkoncentráció időbeli változását külön vizsgálták a varratban és a hőhatásövezetben és feltételezték, hogy a kettő eltér egymástól, amint azt a 4. ábra mutatja. Ezt a különbséget a varrat és a hőhatásövezet eltérő hőterhelésének tulajdonították.

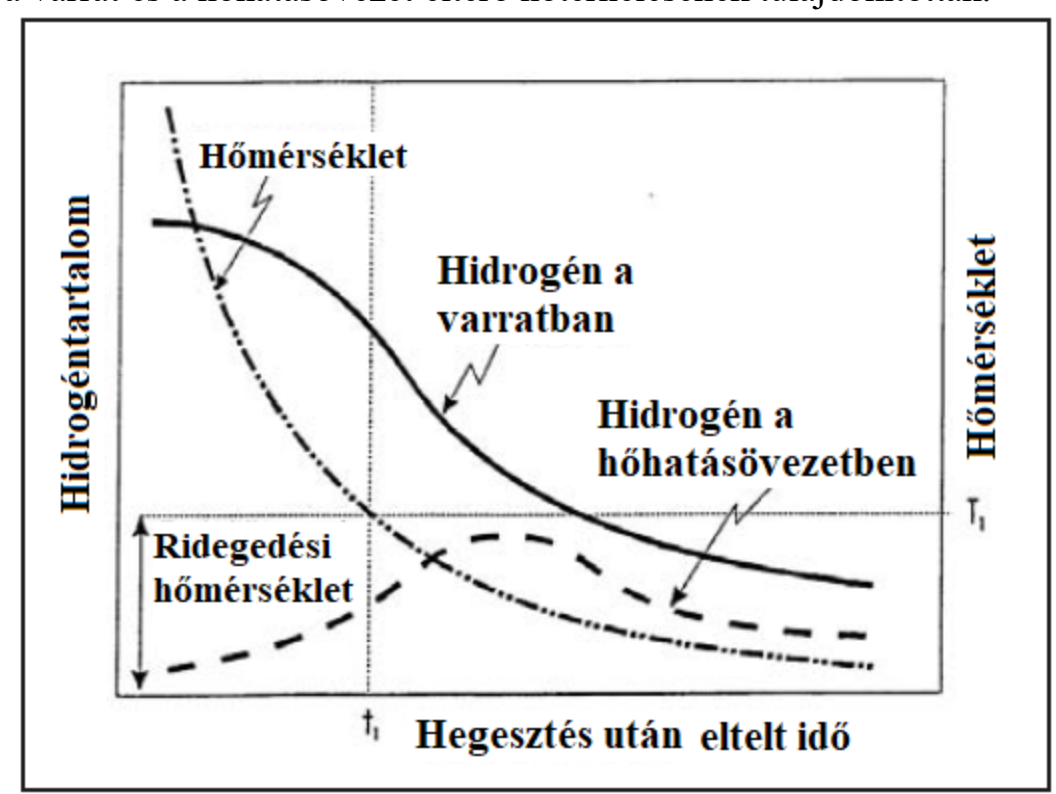

4. ábra. A varrat és a hőhatásövezet hidrogéntartalmának változása hegesztés után [13]

A varrat és a hőhatásövezet feszültségének hegesztés utáni változását szemlélteti az 5. ábra. Nyilvánvaló, hogy alacsonyabb keménységü varrat esetén a hidegrepedés a hőhatásövezetben fog megjelenni, mivel a hidegrepedés kialakulásához szükséges feszültségszint a varratban magasabb, mint a hőhatásövezetben. Másrészről, keményebb varrat esetén a repedés a varratban kezdődik, mivel a hi- 
degrepedéshez szükséges kritikus feszültség a varratban korábban jelenik meg, mint a hőhatásövezetben $[11,13,16,19]$.

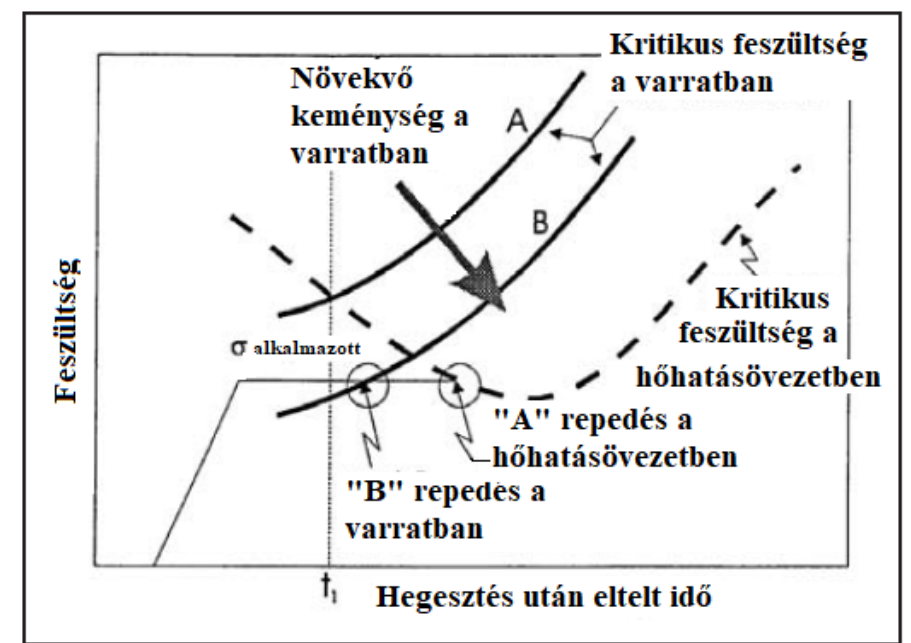

5. ábra. A varrat és a höhatásövezet feszültségének változása hegesztés után [13]

A: kis varrat keménység, repedés keletkezése a hőhatásövezetben

B: nagy varrat keménység, repedés keletkezése a varratban

Vizsgálatok alapján a különböző anyagminőségek esetén különböző hidrogéntartalom megengedhető a repedések elkerülése érdében. A kis szilárdságú S355 acél hegesztésénél a hőhatásövezet megfelelő alakíthatósággal rendelkezik egészen $8 \mathrm{ppm}$ hidrogén tartalomig. Összehasonlításképpen, S690Q acélnál a megengedhető hidrogén tartalom maximum 3ppm lehet, míg S960QL és S1100QL anyagminőségeknél már csak 2 ppm [9].

\section{A hidegrepedés mechanizmusa}

A hidrogén okozta hidegrepedés terjedésének magyarázatára számtalan mechanizmust alkottak, azonban egyik mechanizmus sem magyarázza el teljesen a hidegrepedés terjedését, és mai napig viták vannak arról, hogy melyik a legpontosabb leírás. Összefoglalva ezeket a mechanizmusokat, a hidrogén okozta hidegrepedés kialakulásának sorrendje a következőképpen írható le [13].

- A hegesztőív atmoszféra közelében található nedvesség felbomlik hidrogénmolekulákká, hidrogénatomokká és hidrogénionokká.

- A hidrogén molekulák, atomok és ionok feloldódnak az olvadt hegfürdőben.

- A hegesztett fém lehülése és megszilárdulása során a hidrogénnel túltelítetté válik.

- A hegesztett fémben a túltelített hidrogén hajlamos a hőhatásövezetbe történő vándorlásra.

- Ha a hőhatásövezet ausztenites, a hegesztett fémben található hidrogén bediffundál a beolvadási vonalon keresztül a hőhatásövezetbe, mivel az ausztenitnek jobb a hidrogénoldó képessége. Ha a hőhatásövezet a varrat elött alakul át, azaz, ha a varrat ausztenites, akkor a hidrogén a varratban marad.

- Amíg a hidrogén feloldódik az ausztenites varratban vagy hőhatásövezetben, a gyors lehülés során az ausztenit átalakul a repedésekre érzékeny martenzitté vagy bénitté. Az ausztenitben ténylegesen oldott hidrogén így magas energiájú állapotban marad a bénitben vagy martenzitben. 
- A nagy energiájú hidrogén diffúzió segítségével a rácshibákban és az anyagfolytonossági hiányokban halmozódik fel.

- A hegesztett kötésben maradó húzófeszültség, amelyet az átalakulás miatti térfogatváltozások generálnak - és amelyet további külső korlátok egészítenek ki -, a felhalmozódott hidrogénnel közösen a rács folytonossági hiányait repedés méretüre növelik. A felhalmozódott hidrogén felgyorsíthatja a repedést azáltal, hogy csökkenti a fémrács kohéziós szilárdságát. Ha a repedés kialakult, akkor úgy növekszik, ahogy nő az adott repedésnél a hidrogén koncentráció.

- A repedés növekedésével a repedés csúcsa eltávolodik a hidrogén koncentrációjának pontjától, majd a hidrogén a repedés csúcshoz diffundál, hogy megkönnyítse a további repedésnövekedést.

Mivel a hidrogén a hidegrepedésért felelős három tényező egyike, ezért el kell távolítani vagy csökkenteni kell a varratba kerülő hidrogéntartalmat. A varratba kerülö hidrogéntartalomnak csak egy része képes diffúzióra. A hőmérséklettől függően az elnyelt hidrogén egy része „csapdában” marad a varratban. Ezt a hidrogén tartalmat nevezzük maradó hidrogéntartalomnak. A maradó hidrogéntartalom nem járul hozzá a repedések kialakulásához, mivel nem képes diffúzióra. Az elnyelt hidrogén másik része, amely szabadon diffundálhat a hegesztett kötésen belül és kívül is, diffúzióképes hidrogénként ismert. Elfogadott tény, hogy a diffúzióképes hidrogén a felelős a repedések kialakulásáért, mivel azok képesek csak vándorolni. Ezért szükséges, hogy a varrat diffúzióképes hidrogéntartalmát meghatározzuk $[13,20]$.

\section{A hidegrepedés kialakulásának megakadályozása}

A hidegrepedés előfordulása csekély valószínüségü, ha a három kiváltó tényező közül akár csak az egyik is hiányzik: repedésre hajlamos szövetszerkezet, maradó feszültség és elegendő diffúzióképes hidrogéntartalom.

Számos megoldás létezik arra, hogy csökkentsük a hidegrepedés kialakulásnak veszélyét a hidrogén felvétel korlátozásával. Ez megoldható például az elektrolitikus reakciók hidrogénfelvételének csökkentésével, korróziógátlók adagolásával vagy olyan bevonat alkalmazásával, amely nem engedi át a hidrogént. Ezenkívül, különböző ötvöző elemek, például $\mathrm{V}$, Ti vagy $\mathrm{B}$ is alkalmazható az anyag hidrogén oldóképességének befolyásolására. A maradó feszültséget és a kialakuló szövet keménységét nehéz befolyásolni, ezért általában a diffúzióképes hidrogéntartalmat szokták. Mivel a diffúzióképes hidrogén fö forrása hegesztés estén az elektróda nedvességtartalma, ezért a varratba kerülő hidrogén mennyiségét az elektródák szárításával lehet csökkenteni. A cellulózos bevonattal ellátott elektródák hidrogénben gazdag ívatmoszférát hoznak létre az ív körül. Ennek következtében hidegrepedésre hajlamos acélok esetén tilos cellulózos elektródával hegeszteni $[8,9,13,16]$.

A hidegrepedés kockázatának lecsökkentésére a legjobb módszer a hülési sebesség csökkentése. A kisebb hülési sebesség több időt biztosít a hidrogénnek, hogy kidiffundáljon a varratból. A kis hülési sebesség megkönnyíti a ferrites és perlites szövetek kialakulását is, amelyek kevésbé érzékenyek a hidegrepedésre, mint a martenzit vagy a bénit. Az egyik leggyakrabban alkalmazott módja a hütési sebesség csökkentésének a höbevitel növelése; azonban ez hátrányosan befolyásolhatja a varrat mechanikai tulajdonságait $[8,9,13,16]$.

A hegesztés során elnyelt hidrogén mennyiségének csökkentése érdekében a jelenlegi szabványok különböző hőhatásokat javasolnak, például előmelegítést, hosszabb hőntartást és utóhőkezeléseket. A cél a hidrogén diffúzió idejének meghosszabbítása növelt hőmérsékleten; azonban figyelembe kell venni, hogy a növelt hömérséklet (elömelegités és rétegközi hömérséklet) megnövelheti a hegesztési 
maradó feszültséget. Ennek megfelelően a legegyszerübb és leggyakrabban használt technológia a hidegrepedés kialakulásának csökkentésére a hegesztési alapanyag előmelegítése $[8,9,13,16]$.

Két alapvető módszer létezik az acélok hegesztésénél alkalmazandó biztonságos előmelegítési hőmérséklet meghatározására. Ezen módszerek egyike, a keménységszabályozáson alapul. Segítségével a hőhatásövezet szövetszerkezete és keménysége optimálisabb lesz a hidegrepedés elkerülésére. A másik módszer pedig a hidrogén szint szabályozási módszer, amely a diffúzióképes hidrogéntartalom csökkentésére helyezi a hangsúlyt. Az optimális módszer megválasztása a karbon és egyéb ötvözők mennyisége alapján történik. A hidegrepedéssel kapcsolatos tanulmányokban, a különféle ötvözöelemeket a hidegrepedés kialakulására gyakorolt hatásuk alapján egyetlen tényezővel fejezik ki, amelyet karbonegyenértékként ismerünk (CE). A karbonegyenérték becslésének több módja van, attól függően melyik kutató vagy kutatócsoport alkotta az adott képletet. A karbonegyenérték mindig csak az acél egy összetételi tartományában érvényes. Általánosságban elmondható, hogy ha nő a karbonegyenérték, akkor a hidegrepedés kialakulásának a veszélye is magasabb. Érdemes megjegyezni, hogy az ötvözötartalom növekedésével a CE növekszik, és az acélok még alacsony karbontartalom és magas ötvözőtartalom esetén is hajlamosak a hidegrepedésre. A hidegrepedés elkerülése érdekében szintén alkalmazhatók különböző utóhőkezelési eljárások is, azonban ezek többnyire idő- és költségigényes eljárások, ezért a hidrogénfelvételt már a hegesztési folyamat paramétereivel érdemes elkezdeni szabályozni $[8,9,13,16]$.

\section{A diffúzióképes hidrogéntartalom mérése}

Számos módszer létezik a diffúzióképes hidrogéntartalom meghatározására a hegesztett kötésekben, azonban ezek közül a módszerek közül a különböző szabványok, mint például IIW/ISO, AWS, JIS, DIN stb., csak néhány módszert javasolnak. Az ISO3690:2018(E) szabványban pedig csak három szerepel közülük: a glicerin módszer (glycerin method), mint feltételesen alkalmazható eljárás és a higany módszer (mercury method), amelyekben a hidrogén gyüjtését és mérését szobahőmérsékleten hajtják végre, valamint a hordozógázos módszer (hot carrier gas extraction). Az egyéb alkalmazott módszerek többsége is hasonló a higany vagy glicerin módszerekhez, csak a vizsgálatban alkalmazott folyadéktípusban térnek el egymástól. Ezeknek a módszereknek a hatékonysága látható a higanyos módszerhez képest az 1. táblázatban [13, 21].

1. táblázat A diffúzióképes hidrogéntartalom meghatározásának hatékonysága különböző gyűjtő közegek esetén [13, 23-25]

\begin{tabular}{|c|c|}
\hline Gyüjtö közeg & Hatékonyság [\%] \\
\hline Higany & 100 \\
\hline $10 \mathrm{~N} \mathrm{~K}_{2} \mathrm{CO}_{3}$ & $38-42$ \\
\hline Víz & $2-8$ \\
\hline Szilikonolaj & $5-32$ \\
\hline Glicerin & $79-88$ \\
\hline Etil alkohol & $23-39$ \\
\hline Desztillált víz & $58-72$ \\
\hline Etilén-glikol & $18-32$ \\
\hline Paraffin & $10-19$ \\
\hline Szén-tetraklorid & $10-20$ \\
\hline
\end{tabular}


A diffúzióképes hidrogéntartalom meghatározásának egyik módszere a higany módszer, amelynek a jelenleg elfogadott változatát az ISO 3690:2018(E) szabvány tartalmazza. A szabvány alapján egy szabályos méretü próbatestre egy varratsort kell hegeszteni, majd a hegesztés után gyorsan le kell hüteni azt. Ezt követően, a próbatestet bürettába helyezve, az eltávozó hidrogént összegyüjtik. Az összegyült hidrogén mennyiségét a hőmérséklettel és nyomással korrigálni kell [21]:

$$
V=\frac{273 \cdot(p-h) \pi r^{2} C}{760 *(273+T) \cdot 1000},
$$

ahol V: a hidrogén mennyisége [ml], p: a légnyomás [mm] (higanyra vonatkozóan), h: a higanyszint különbsége a büretta két ága között [mm], r: a kapilláris csőszakasz belső sugara [mm], C: a gázoszlop hossza a higany felett [mm], T: szobahőmérséklet a mérés ideje alatt $\left[{ }^{\circ} \mathrm{C}\right]$.

Ezt követően a próbatestet el kell távolítani a készülékből és meg kell határozni a tömegét $0,1 \mathrm{~g}$ (egyes esetekben $0,01 \mathrm{~g}$ ) pontossággal. A $100 \mathrm{~g}$ varratra vonatkoztatott hidrogén mennyiségét az alábbi összefüggéssel számíthatjuk [21]:

$$
H_{D}=V_{S T P} * \frac{100}{m_{2}-m_{1}}
$$

ahol $\mathrm{H}_{\mathrm{D}}$ : a hegesztett próbatest diffúzióképes hidrogéntartalma $[\mathrm{ml} / 100 \mathrm{~g}], \mathrm{V}_{\mathrm{STP}}$ : hidrogén mennyisége normál hőmérsékleten és nyomáson $[\mathrm{ml}], \mathrm{m}_{2}$ : a hegesztett próbatest tömege $[\mathrm{g}], \mathrm{m}_{1}:$ a próbatest tömege hegesztés elött $[\mathrm{g}]$.

A hidrogén mennyiségét vonatkozhatjuk a varrat tömegére is, de ez esetben a varrat keresztmetszetét meg kell határozni [21].

A diffúzióképes hidrogéntartalom meghatározásánál fontos az eljárás paramétereinek pontos elöírása és azok betartása. A szabványos, rézből készült befogószerkezetet mutatja a 6. ábra [7].

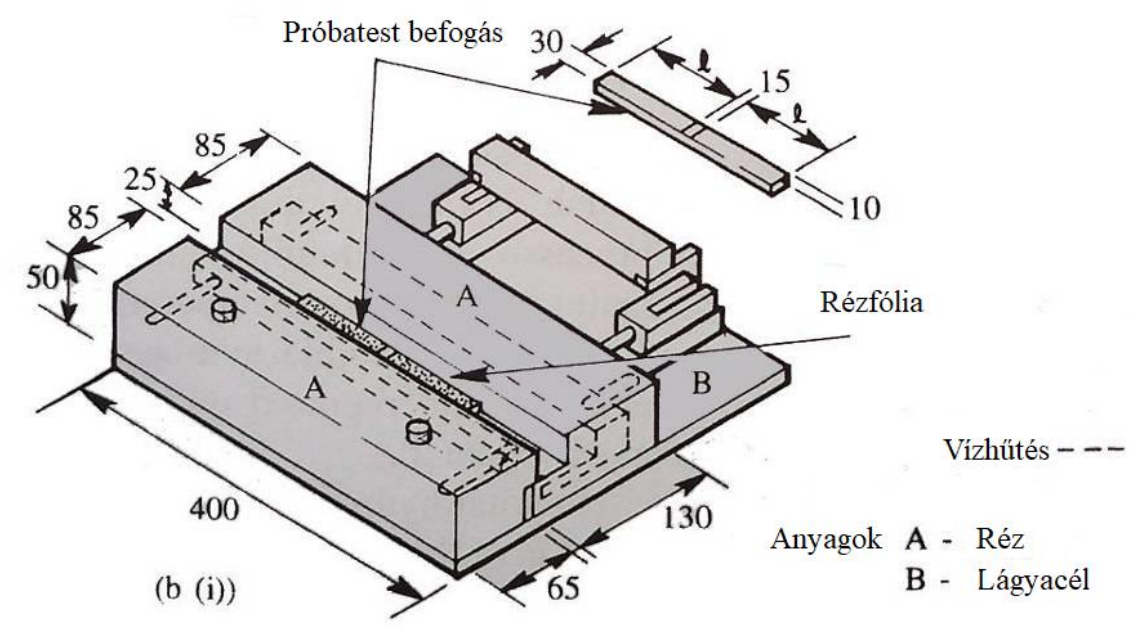

6. ábra. Egy szabványos vízhütéses befogó készülék rajza és méretei [7]

A vizsgálat elvégzése során a próbatestekkel, a hegesztési technológiával és egyéb körülményekkel kapcsolatban számos előírást kell figyelembe venni, a mérés pontossága és reprodukálhatósága érdekében. Ezeket az elöírásokat a szabvány részletesen tartalmazza. A szabványok $45^{\circ} \mathrm{C}$-os hőmérsékleten 
72 órás vizsgálati időt, míg $150^{\circ} \mathrm{C}$-on már csak 6 órás vizsgálati időt írnak elő. Ezen a hőmérsékleten viszont a higany erősen párolog, aminek az egészségügyi kockázata magas [21].

A diffúzióképes hidrogéntartalom mérésére szolgáló egyik régebbi eljárás a ma is alkalmazható glicerin módszer. Maga a módszer nagyon hasonló a higanyos módszerhez, viszont ebben az esetben a gyüjtőközeg a glicerin. Ezzel az eljárással lényegesen kedvesebb a vizsgálat során kapott hidrogén mennyisége, mint a higanyos módszer alkalmazásakor. Ezt az eltérést elsősorban a hidrogén eltérő oldhatósága okozza a munkafolyadékban. Ennek a hatásnak a kiküszöbölésére, a szabványok alapján, laboratóriumi körülmények között van lehetőség, különböző összefüggések meghatározásával, a higanyos módszerhez viszonyítva a megbízható és reprodukálható eredmények eléréséhez. Ilyen összefüg-

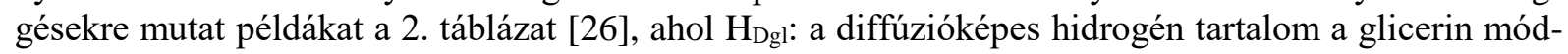

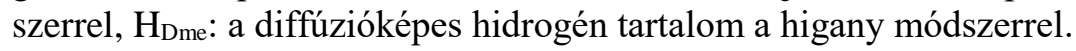

2. táblázat A glicerin és a higany módszer eredményeinek kapcsolata

\begin{tabular}{|c|c|}
\hline Összefüggés & Forrás \\
\hline $\mathrm{H}_{\text {Dgl }}=0.81 \times \mathrm{H}_{\text {Dme }}-1.71$ & {$[26]$} \\
\hline $\mathrm{H}_{\text {Dgl }}=0.64 \times \mathrm{H}_{\text {Dme }}-0.93$ & {$[27]$} \\
\hline $\mathrm{H}_{\text {Dgl }}=0.67 \times \mathrm{H}_{\text {Dme }}-0.80$ & {$[28]$} \\
\hline $\mathrm{H}_{\text {Dgl }}=0.79 \times \mathrm{H}_{\text {Dme }}-1.73$ & {$[29]$} \\
\hline $\mathrm{H}_{\text {Dgl }}=0.658 \times \mathrm{H}_{\text {Dme }}$ & {$[30]$} \\
\hline
\end{tabular}

A 2. táblázatban bemutatott összefüggések különbözőnek látszanak egymástól, de a grafikus ábrázolás (7. ábra) alapján csak kis különbség van közöttük.

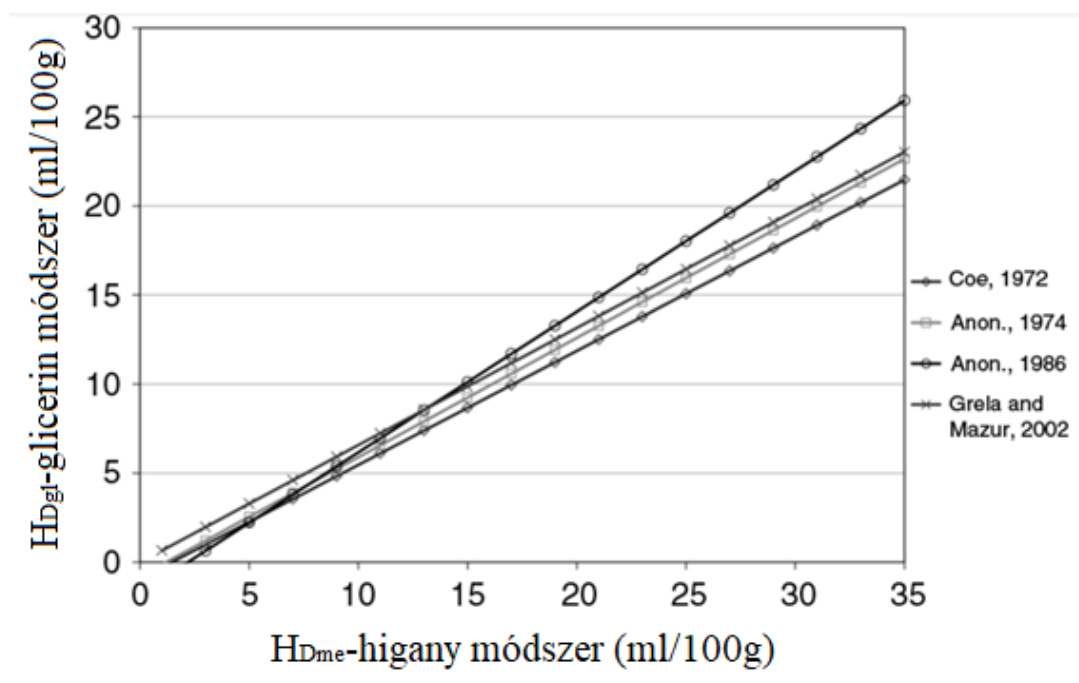

7. ábra. A glicerin és a higany módszer eredményeinek összehasonlítása [26-30]

Mivel a megfelelő összefüggés segítségével jól alkalmazható ez az eljárás is, alkalmazása elterjedt; azonban meg kell említeni azt is, hogy $5 \mathrm{ml} / 100 \mathrm{~g}$ alatti hidrogéntartalom esetén már nem javasolt az alkalmazása [26].

A hordozógázos módszer lényege, hogy a próbatestet kemencében, maximum $400{ }^{\circ} \mathrm{C}$-ra melegítik, inert gázban, például argonban. A próbatestből távozó hidrogén elegyedik az argon gázzal, amelynek hővezető képessége a hidrogén mennyiségi arányától függően megváltozik. A hővezető képesség 
megváltozását gázkromatográffal mérik. A mérés pontossága érdekében az argon gáz tisztaságát és áramlási mennyiségét pontosan szabályozni és ellenőrizni kell. A diffúzióképes hidrogén összegyüjtéséhez szükséges idő $45^{\circ} \mathrm{C}$-on kb. 72 óra, míg $400{ }^{\circ} \mathrm{C}$-on csupán 35 perc. $400{ }^{\circ} \mathrm{C}$ feletti hömérsékleten megnő a veszélye annak, hogy a vegyület formájában kötött hidrogén is eltávozik a próbatestböl. Ilyenkor a diffúzióképes és a maradó hidrogén együttes mennyiségét határozzuk meg, amely a hegesztési repedések kockázatának megítélése szempontjából nem használható adat. Az eltávozó hidrogén oxidációjának elkerülése érdekében, $300{ }^{\circ} \mathrm{C}$ feletti extrakció esetén, a próbatest felületén lévő oxidokat is el kell távolítani [7, 21].

\section{9. Összefoglalás}

A hegesztett szerkezetek megbízhatósága fokozott követelményeket támaszt a hegesztési technológiával szemben. A technológia kidolgozásához szükséges információs bázis részét képezi a hidrogéntartalom ismerete, mivel a diffúzióképes hidrogéntartalom a hidegrepedések keletkezésének egyik kiváltó oka (a repedésre hajlamos szövetszerkezet és mechanikai feszültség mellett). A hegesztés során a hidrogén forrása lehet a hegesztési hely környezetében megjelenő víz, a lecsapódó pára, a csapadék, a bevonat vagy a fedőpor nedvességtartalma, illetve a védőgáz, az alapanyag vagy a hozaganyag felületén található rozsda és szerves anyag (festék, zsír, olaj). A repedések elkerülése érdekében, a hegesztés során biztosítani kell, hogy a diffúzióképes hidrogéntartalom szabályozott legyen, valamint, hogy elegendő idő álljon rendelkezésre ahhoz, hogy a hidrogén diffúzió segítéségével eltávozzon a varratból, mielőtt az környezeti hőmérsékletre hül. Ebből kifolyólag a diffúzióképes hidrogéntartalom megfelelő ismerete elengedhetetlen az optimális előmelegítési hőmérséklet kiválasztásához a hidegrepedés kockázatának elkerülése érdekében.

A hidegrepedés mechanizmusának magyarázatára különböző elméletek léteznek, de ezen mechanizmusok egyike sem magyarázza terjes mértékben a hidegrepedést. Ahhoz, hogy a hidegrepedést jobban megérthessük, a hegesztett kötés helyi hidrogéntartalmának mérésére van szükség, amelyre napjainkban számos módszer áll rendelkezésre. Ezek közül a módszerek közül a különböző szabványok, mint az IIW/ISO, az AWS stb. csak néhány módszert javasolnak. Ide tartozik a glicerin módszer és a higany módszer, amelyekben a hidrogén gyüjtését és mérését szobahőmérsékleten hajtják végre, valamint a hordozógázos módszer.

Az anyagok folyamatos fejlesztése okán még nagyobb figyelmet igényel a hidrogén jelenléte a hegesztett kötésben. Egy alacsony szilárdságú, például S355 acél esetén a megengedett hidrogénkoncentráció a höhatásövezetben 8ppm-ig terjedhet, S690Q esetén ez a határérték csak körülbelül 3 ppm, míg S1100QL esetén már 2 ppm alatt van.

\section{Köszönetnyilvánítás}

A cikkben ismertetett kutató munka az EFOP-3.6.1-16-2016-00011 jelü „Fiatalodó és Megújuló Egyetem - Innovativ Tudásváros - a Miskolci Egyetem intelligens szakosodást szolgáló intézményi fejlesztése" projekt részeként - a Széchenyi 2020 keretében - az Európai Unió támogatásával, az Európai Szociális Alap társfinanszírozásával valósult meg.

\section{Irodalom}

[1] Lukács, J., Nagy, Gy., Harmati, I., K. Fótos, R., K. Koncsik Zs.: Szemelvények a mérnöki szerkezetek integritása témaköréböl (szerk. Lukács, J.), Miskolci Egyetem, Miskolc, 2012, ISBN 978-963-358-000-4. 
[2] Koncsik, Zs.: A szerkezetintegritás helye és szerepe az oktatásban és a kutatásban, Multidiszciplináris Tudományok 2019, 9: 63-71. https://doi.org/10.35925/j.multi.2019.4.5

[3] E. Van den Eeckhout, I. De Baere, T. Depover, K. Verbeken: The effect of a constant tensile load on the hydrogen diffusivity in dual phase steel by electrochemical permeation experiments, $\begin{array}{llllll}\text { Materials Science } \quad \text { \& } & \text { Engineering 2020, }\end{array}$ https://doi.org/10.1016/j.msea.2019.138872

[4] W.H. Johnson: On some remarkable change produced in iron and steel by the action of hydrogen and acids, Proc. R. Soc. Lond. 1875, 23: 168-179. https://doi.org/10.1098/rspl.1874.0024

[5] J. C. Villalobos, A. Del-Pozo, B. Campillo, J. Mayen, S. Serna: Microalloyed steels through history until 2018: Review of chemical composition, processing and hydrogen service, Metals, 2018, 8: 351. https://doi.org/10.3390/met8050351

[6] T. Schaupp, W. Ernst, H. Spindler, T. Kannengiesser: Hydrogen-assisted cracking of GMA welded 960 MPa grade high-strength steels, International journal of hydrogen energy 2020, 45: 20080-20093. https://doi.org/10.1016/j.ijhydene.2020.05.077

[7] Fehérvári G.: Diffúzióképes hidrogéntartalom meghatározása hegesztési varratokban, Szakdolgozat, Budapesti Múszaki és Gazdaságtudományi Egyetem, 2010.

[8] S. Salmi, M. Rhode, S. Jüttner, M. Zinke: Hydrogen determination in 22 MnB5 steel grade by use of carrier gas hot extraction technique, Weld World 2015, 59: 137-144. https://doi.org/10.1007/s40194-014-0186-z

[9] T. Schaupp, M. Rhode, T. Kannengiesser: Influence of welding parameters on diffusible hydrogen content in high-strength steel welds using modified spray arc process, Welding in the World 2018, 62: 9-18. https://doi.org/10.1007/s40194-017-0535-9

[10] Komócsin M.: Anyagok hegeszthetösége, Digitális tankönyvtár, 3.3 fejezet, 2013.

[11] E. Steppan, P. Mantzke, B. R. Steffens, M. Rhode, T. Kannengiesser: Thermal desorption analysis for hydrogen trapping in microalloyed high-strength steels, Weld World 2017, 61:637-648.

[12] E. Betz, H. K. Leung: Technical note: Hydrogen diffusion in welded joints and its relation to lamellar tearing, Welding Research Supplement, June, 1979, pp 177-178.

[13] P. Girish Kumar, K. Yu-ichi: Diffusible Hydrogen in Steel Weldments - A status review, Transactions of JWRI 2013, 42(1): 39-62.

[14] R. C. Souza, L. R. Pereira, L. M. Starling, J. N. Pereira, T. A. Simões, J. A. C. P. Gomes, A. H. S. Bueno: Effect of microstructure on hydrogen diffusion in weld and API X52 pipeline steel base metals under cathodic protection, International Journal of Corrosion 2017: 4927210. https://doi.org/10.1155/2017/4927210

[15] H. Jürgen Grabke, E. Riecke: Absorption and diffusion of hydrogen in steels, Mater. Tehnol. 2000, 34: 331-342.

[16] T. Schaupp, M. Rhode, H. Yahyaoui, T. Kannengiesser: Influence of heat control on hydrogen distribution in high-strength multi-layer welds with narrow groove, Welding in the World, 2019, 63: 607-616. https://doi.org/10.1007/s40194-018-00682-0

[17] Z. Xiong, W. Zheng, L. Tang, J. Yang: Self-gathering effect of the hydrogen diffusion in welding induced by the solid-state phase transformation, Materials 2019, 12: 2897. https://doi.org/10.3390/ma12182897

[18] J. Yang, G. Liu, W. Zheng: Study on Hydrogen Diffusion Behavior during Welding of Heavy Plate, Materials, 2020, 13: 3887. https://doi.org/10.3390/ma13173887 
[19] W. L. Costin, O. Lavigne, A. Kotousov, R. Ghomashchi, V. Linton: Investigation of hydrogen assisted cracking in acicular ferrite using site-specific micro-fracture tests, Materials Science \& Engineering 2016, A 651: 859-868. https://doi.org/10.1016/j.msea.2015.11.044

[20] U. Yadav, C. Pandey, N. Saini, J. G. Thakre, M. M. Mahapatra: Study on hydrogen-assisted cracking in high-strength steels by using the Granjon implant test, Metallogr. Microstruct. Anal. 2017, 6: 247-257. https://doi.org/10.1007/s13632-017-0351-z

[21] ISO 3690:2018(E): Welding and allied processes - Determination of hydrogen content in arc weld metal.

[22] M.A. Quintana: Welding Journal 1984, 63(5): 141-149.

[23] Y. Kikuta, T. Araki, A. Ookubo, H. Ootani: Journal of Japan Welding Society 1976, 45(2): 1008-1015. https://doi.org/10.2207/qijwss1943.45.1008

[24] M. A. Quintana, J. R. Dannecker: Hydrogen Embrittlement, prevention and Control, ASTM 1988, STP 962: 247-268.

[25] G.C. Schmid, R.D. Rodabaugh: Welding Journal 1980, 58(8): 217-225.

[26] D. Fydrych, J. Labanowski: An experimental study of high-hydrogen welding processes, Revista De Metalurgia, 2015, 51(4): e055. https://doi.org/10.3989/revmetalm.055

[27] Coe F.R.: The comparison of hydrogen levels. International Institute of Welding Document IIW Doc. II-A-305-1972, 1972.

[28] Anon.: Relation between hydrogen contents by IIW and JIS method. International Institute of Welding, Document IIW Doc. II-698-74. 1974.

[29] Anon.: Method of measurement for hydrogen evolved from steel welds. International Institute of Welding, Document IIW Doc. II-1073-86. 1986.

[30] Grela P., Mazur M.: Comparison investigations of hydrogen diffusing from weld deposit determined by glycerin and mercury methods. Institute of Welding Bulletin 2002, 46: 54-55. 